\title{
Comparative Analysis between Ecotoxicity of Nitrogen-, Phosphorus-, and Potassium-Based Fertilizers and Their Active Ingredients
}

\author{
Nathan de Castro Soares Simplício ${ }^{1,2,3}$, Daphne Heloísa de Freitas Muniz ${ }^{1}$, \\ Fernanda Regina Moreira Rocha ${ }^{2}$, Denis Cavalcanti Martins ${ }^{2}$, Zélia Malena Barreira Dias ${ }^{3}$, \\ Bruno Pereira da Costa Farias ${ }^{2}$ and Eduardo Cyrino Oliveira-Filho 1,2,3,* \\ 1 Embrapa Cerrados, Rodovia BR 020, Km 18, Planaltina DF 73310-970, Brazil; \\ nathan.simplicio@globo.com (N.d.C.S.S.); daphne.muniz@embrapa.br (D.H.d.F.M.) \\ 2 Faculdade de Ciências da Educação e Saúde (FACES), Centro Universitário de Brasília (UniCEUB), \\ Brasília DF 70790-075, Brazil; fernandarmr9@gmail.com (F.R.M.R.); deniscavm@gmail.com (D.C.M.); \\ bruno.faria85@gmail.com (B.P.d.C.F.) \\ 3 Faculdade UnB Planaltina, Campus de Planaltina Área Universitária 01, Universidade de Brasília (UnB), \\ Planaltina DF 73345-010, Brazil; zelia.malena@hotmail.com \\ * Correspondence: eduardo.cyrino@embrapa.br; Tel.: +55-61-3388-9894
}

Academic Editor: David Bellinger

Received: 29 September 2016; Accepted: 20 December 2016; Published: 27 December 2016

\begin{abstract}
This study aimed to analyze the ecotoxicity of nitrogen-, phosphorus-, and potassium-based compounds to organisms of two different trophic levels in order to compare the toxic effect between high-purity substances and these substances as components of fertilizers. Dilutions were made with the fertilizers' potassium chloride, potassium nitrate, superphosphate, urea, and their equivalent reagents, to conduct assays to establish the acute lethal concentration for half of the population (LC50). Ten individuals of the benthic snail Biomphalaria glabrata and the fish Danio rerio were exposed to each concentration of tested compounds. As a result, the toxicity levels of potassium chloride, potassium nitrate, and urea were obtained for B. glabrata and D. rerio, with the fish being more susceptible to potassium chloride in the fertilizer and the snail to potassium nitrate and urea, in both commercial and reagent forms. Regarding superphosphate, no significant toxicity was found. This study concluded that among the tested substances, $\mathrm{KNO}_{3}$ and $\mathrm{KCl}$ were the most toxic substances and urea the least toxic. It was not possible to establish the most sensitive species since, for $\mathrm{KCl}$, the fish were more susceptible to the fertilizer and the snail to the reagent, while for $\mathrm{KNO}_{3}$ the opposite was observed.
\end{abstract}

Keywords: bioassays; agriculture; lethal concentration; environmental chemistry

\section{Introduction}

Within the agricultural production chain, nitrogen $(\mathrm{N})$, potassium $(\mathrm{K})$, and phosphorus $(\mathrm{P})$ are of great importance for the practice of agriculture. In the production process it is difficult for the farmer to obtain a high yield without using at least phosphate-, nitrogen-, and potassium-based fertilizers. According to the International Fertilizer Industry Association [1], on average 104,252 million tons of nitrogen, 40,522 million tons of phosphate, and 27,435 million tons of potassium are used each season worldwide.

Nitrogen, when in aqueous medium, is converted into ammonia, nitrite, and nitrate in a three-step process [2]. It is known that of these three ions, ammonia is the most toxic to aquatic organisms [3], but these compounds often exist at low concentrations in aquatic ecosystems because they are the main source of nitrogen for primary producers [4]. The ecological imbalances and the risks for human 
consumption are now considered when nitrate and nitrite concentrations become high, due to nutrients deposited in the water body through activities such as agriculture and livestock [3].

Phosphorus can occur in natural and waste waters almost entirely in the form of phosphates. These are classified into orthophosphates, organic phosphates, and condensed phosphates (pyrometaphosphate and other polyphosphates). The third of these is not very relevant to water quality control studies, because condensed phosphates hydrolyze, quickly becoming orthophosphates in natural waters [2]. Orthophosphates are represented by the radicals $\mathrm{PO}_{4}{ }^{3-}, \mathrm{HPO}_{4}{ }^{2-}, \mathrm{H}_{2} \mathrm{PO}_{4}{ }^{-}$, and if combined with cations, these form inorganic salts in the water. The discharge of phosphates from raw or treated sewage, agricultural drainage, or certain industrial waste can stimulate the growth of micro and macro photosynthetic organisms in large amounts, triggering the eutrophication process [2].

Potassium (K) is one of the elements most needed by crops; however, its fixation in the soil is more difficult since its salts have low cation exchange capacity $[5,6]$. This compound is usually extracted from marine sedimentary deposit sources in the form of $\mathrm{KCl}$ or potassium sulfate $\left(\mathrm{K}_{2} \mathrm{SO}_{4}\right)$ [7].

$\mathrm{K}$ is also involved in the salinization of the water process, and in some places this salinization can change the composition of local fauna [8]. Due to this effect on salinity, potassium acts indirectly in the toxicity even when present in small concentrations [9].

In the presence of water, many compounds are biochemically interconverted into ions [2]. Other substances present in these compounds, such as impurities, ions, metals, organic contaminants, and even microorganisms, will interact with elements in the environment [10]. When they are transported to a water source, such as lakes, streams, and ponds, the compounds generally undergo alterations in quantity, be it dilution, reconcentration, or transfer. They also undergo alterations in their quality, being changed by degradation processes or multiple reactions that may act during the transport process, forming compounds with distinct properties; in turn, these may even increase or decrease the toxicity of the compound [11].

Works that deal with the action of these ions alone are important in the literature, since the interaction of the elements in the environment can induce toxicity in others [12], as occurs with potassium. It has been observed that when in ionic form, potassium compounds raise the toxicity of other chemicals, such as nitrate $[9,10]$, and that the different forms of soluble nitrogen can define their impact on the environment [13-15]. Another study showed that, when in an aqueous solution, cadmium has its toxic effect maximized, depending upon the calcium concentrations in the water [16]. It has also been observed that diluted calcium can reduce the toxicity of phosphate by promoting its precipitation $[17,18]$.

The choice was made to use a chemical reagent and a commercial fertilizer in this study after the authors reviewed articles on the ecotoxicology of compounds used as fertilizers. Those that reported the origin of the element used showed a preference for chemical reagents instead of commercial fertilizers. This fact has some implications within the results analysis, because most of the commercialized fertilizers do not possess the purity that chemical reagents present. Indeed, the purity of potassium in a commercial fertilizer can range from $18 \%$ to $60 \%$ depending on the fertilizer and the manufacturer [19]. This range makes it difficult to understand if the toxicity is related to the test substance or to impurities contained in the commercial product formulation.

The study aimed to analyze the toxicity of nitrogen-, phosphorus-, and potassium-based compounds in different forms in two organisms from different trophic levels in order to compare the toxic effect between high-purity substances and those used as a component of fertilizer, seeking to identify the element present in the compound responsible for toxicity and the increase or reduction in toxicity.

\section{Materials and Methods}

The species used in this study were the benthic snail (Biomphalaria glabrata) and the zebrafish (Danio rerio), involving species from two different trophic levels, the first one being a mollusk and the second a fish. Both are freshwater organisms, aiming to cover organisms with distinct biological 
characteristics and habits, since the snail is a benthic organism and the fish is pelagic. Many studies have already been carried out with planktonic organisms, but few with benthic organisms and, thus, the need to evaluate a model of this trophic level. Fish were included because they are key organisms in aquatic environments, and to be able to obtain a comparative susceptibility with the snails.

The main fertilizers used in the Brazilian Cerrado (high savanna) were used for the study, namely potassium chloride $(\mathrm{KCl})$, potassium nitrate $\left(\mathrm{KNO}_{3}\right)$, single superphosphate $\left(\mathrm{Ca}\left(\mathrm{H}_{2} \mathrm{PO}_{4}\right)_{2}+\mathrm{CaSO}_{4}\right)$, and urea $\left(\mathrm{CO}\left(\mathrm{NH}_{2}\right)_{2}\right)$. From this choice, dilutions were made of the respective commercial fertilizers $(\mathrm{CF})$, and their equivalent chemical reagents $(\mathrm{CR})$ were used as active ingredients, namely, potassium chloride, J.T. Baker ${ }^{\circledR}$ (purity 99.8\%) (J.T. Baker ${ }^{\circledR}$, Xalostoc, Mexico), potassium nitrate, Impex ${ }^{\circledR}$ (purity 99\%) (Impex, RS, Brazil), urea, Merck ${ }^{\circledR}$ (purity 100\%) (Merck ${ }^{\circledR}$, Darmstadt, Germany) and potassium phosphate monobasic, Merck ${ }^{\circledR}$ (purity 99.5\%) (Merck ${ }^{\circledR}$, Darmstadt, Germany); the latter was used for comparison with superphosphate.

The dilution concentrations ranged from 75 to $3000 \mathrm{mg} \cdot \mathrm{L}^{-1}$ for the $\mathrm{CR}$ and 100 to $3000 \mathrm{mg} \cdot \mathrm{L}^{-1}$ for the CF. For urea, which is known to trigger mortality at higher concentrations, dilutions ranged from $1000-40,000 \mathrm{mg} \cdot \mathrm{L}^{-1}$ for the CR and $10,000-40,000 \mathrm{mg} \cdot \mathrm{L}^{-1}$ for the CF. All of these concentrations were defined based on preliminary tests. The concentrations used in the definitive tests were variable for each CR, being obtained from preliminary tests with about three well-spaced dilutions.

After dilutions, acute assays in laboratory with the chosen organisms were performed to establish the lethal concentration for $50 \%$ of the studied population (LC50). The acute test method for snails was proposed by Oliveira-Filho et al. [20], and for fish the protocol used was standardized by guideline NBR 15088 of the Brazilian Association for Technical Standardization [21]. For all organisms, LC50s and their respective 95\% confidence intervals were determined by the Trimmed Spearman Karber program [22] version 1.5 .

In tests with snails the static exposure system was used, and the solutions were prepared only at the beginning of the test, without renewal until the end of exposure. For urea, in particular, and for all tests with fish, the semi-static methodology was used, where solutions were renewed daily to avoid losses by volatilization and degradation, as recommended by guideline EPA 821-R-02-012 [23]. During the test, $\mathrm{pH}$ and dissolved oxygen were checked daily with the intention of identifying possible abrupt changes in those parameters during the exposure period.

Before each test, solutions were placed in $2 \mathrm{~L}$ beakers for the snails and $3 \mathrm{~L}$ for the fish and stirred for $24 \mathrm{~h}$ in an orbital shaker. After that, 10 organisms were inserted into each concentration, with the presence of a control group, and the mortality of individuals after 48 and $96 \mathrm{~h}$ of exposure was assessed.

The preparation of the dilution water (reconstituted soft water) for all of the tests followed the standardized protocols under guideline NBR 15088 [21], which involved dissolving $48 \mathrm{mg}$ of sodium bicarbonate $\left(\mathrm{NaHCO}_{3}\right), 30 \mathrm{mg}$ of calcium sulfate $\left(\mathrm{CaSO}_{4}\right), 30 \mathrm{mg}$ of magnesium sulfate $\left(\mathrm{MgSO}_{4}\right)$, and $2 \mathrm{mg}$ of magnesium sulfate $(\mathrm{KCl})$ in $1 \mathrm{~L}$ of distilled water. The $\mathrm{pH}$ of the dilution water was maintained at $7.2 \pm 0.1$ and hardness between $40-48 \mathrm{mg} \cdot \mathrm{L}^{-1}$ as $\mathrm{CaCO}_{3}$.

All applicable international, national, and institutional guidelines for the care and use of animals were followed. All tests with Danio rerio were approved by the Animal Use Commission from the Brasília University Centre-UniCEUB-(file number 003/15), on 19 March 2015.

To ensure the concentrations of the diluted chemicals in the assays, and to define the effective concentrations to be used in the calculation of the LC50, ion chromatography analysis of each sample was performed before and after the assays, including the water destined for the control. Presence of the major component ions ammonium $\left(\mathrm{NH}_{4}{ }^{+}\right)$, potassium $\left(\mathrm{K}^{+}\right)$, chlorine $\left(\mathrm{Cl}^{-}\right)$, nitrate $\left(\mathrm{NO}_{3}{ }^{-}\right)$, and phosphate $\left(\mathrm{PO}_{4}^{3-}\right)$ was analyzed.

The equipment used for this purpose was the Ionic Chromatograph 761 Compact IC, Metrohm. Ion chromatography is a chromatographic technique that applies the principles of ion exchange, so that electrical conductivity is used for the detection and quantitative determination of ions in solution [24]. 
To guarantee quality assurance and quality control of determinations, calibration standards were prepared each day of analysis, using Merck ${ }^{\circledR}$ (Darmstadt, Germany) reagents. Blanks, duplicates, and spiked samples were also used. Calibration coefficients had to maintain at least three nines before proceeding with samples $(\mathrm{r}=0.999)$.

To ascertain if there were any significant differences in nutrient concentrations before and after each test, samples were analyzed before and after the exposure time, and the results obtained from ion chromatography were subjected to statistical analysis. We performed the Shapiro-Wilk normality test with significance level of $5 \%$ ("shapiro.test" function) to define the statistical test to be used. For data with normal distribution, we performed the paired t-test ("t.test" function), while for those that did not obtain normal distribution we performed the Wilcoxon-Mann-Whitney test ("wilcox.test" function).

These statistical procedures were performed with the $\mathrm{R}$ software package, 2.15 .3 version [25] and had the intention of examining only if there was a significant change in the analyzed nutrient concentrations during the exposure period.

\section{Results}

In all tests the analysis of ion chromatography showed, as expected, the presence of chloride $\left(\mathrm{Cl}^{-}\right)$and potassium $\left(\mathrm{K}^{+}\right)$in samples destined for the control group and in the dilution water at concentrations of $0.649 \mathrm{mg} \cdot \mathrm{L}^{-1}$ for $\mathrm{Cl}^{-}$and $2.079 \mathrm{mg} \cdot \mathrm{L}^{-1}$ for $\mathrm{K}^{+}$, as is expected for the use of $\mathrm{KCl}$ in the preparation of the dilution water.

The urea concentrations employed in the experiments had a high variation in chromatographic analyses, a very dynamic degradation when diluted, so when analyzed at some concentrations, the substance already showed a stage that could not be detected.

The Shapiro-Wilk normality test did not show normal distribution for the magnesium variable in $\mathrm{KCl}$ dilutions. For the $\mathrm{KNO}_{3}$ dilutions, the normality test did not show normal distribution either for the potassium or the nitrate. In both cases the sample size was 10. For urea dilutions, the normality test revealed a normal distribution for all of the variables. Finally, for potassium phosphate monobasic and superphosphate, the normality test also showed a normal distribution for all of the variables.

However, neither the $\mathrm{T}$ test nor the Wilcoxon-Mann-Whitney test (for the variable not normally distributed) showed a significant difference between the initial dilution and the final one. As the statistical test showed no significant difference between the chemical analysis performed before and after the tests, in all subsequent tables only the results of analysis before the tests are shown, aiming for a better presentation of the data (Tables 1 and 2).

Table 1. Ion chromatography of the dilutions from the chemical reagents (units: $\mathrm{mg} \cdot \mathrm{L}^{-1}$ ).

\begin{tabular}{|c|c|c|c|c|c|c|}
\hline Substance & Concentration & Ammonium & Potassium & Chloride & Nitrate & Phosphate \\
\hline \multirow[t]{2}{*}{$\mathrm{KCl}$} & $\begin{array}{c}\text { Lowest } \\
\text { Concentration }\end{array}$ & 0.000 & 113.404 & 132.215 & 0.000 & 0.000 \\
\hline & $\begin{array}{l}\text { Highest } \\
\text { Concentration }\end{array}$ & 0.000 & 1038.781 & 1043.386 & 0.000 & 0.000 \\
\hline \multirow[t]{2}{*}{ KNO3 } & $\begin{array}{c}\text { Lowest } \\
\text { Concentration }\end{array}$ & 0.000 & 105.629 & 2.553 & 100.671 & 0.000 \\
\hline & $\begin{array}{c}\text { Highest } \\
\text { Concentration }\end{array}$ & 0.000 & 1343.164 & 0.000 & 1314.378 & 0.000 \\
\hline \multirow[t]{2}{*}{ Urea } & $\begin{array}{c}\text { Lowest } \\
\text { Concentration }\end{array}$ & 0.000 & 1.255 & 1.867 & 0.000 & 0.000 \\
\hline & $\begin{array}{c}\text { Highest } \\
\text { Concentration }\end{array}$ & 12.357 & 0.000 & 1.669 & 0.000 & 0.000 \\
\hline \multirow[t]{2}{*}{ KH2PO4 } & $\begin{array}{c}\text { Lowest } \\
\text { Concentration }\end{array}$ & 0.000 & 22.590 & 0.240 & 0.000 & 66.702 \\
\hline & $\begin{array}{c}\text { Highest } \\
\text { Concentration }\end{array}$ & 0.000 & 1001.143 & 0.000 & 0.000 & 2732.077 \\
\hline Dilution water & - & 0.000 & 2.079 & 0.649 & 0.000 & 0.000 \\
\hline
\end{tabular}


Table 2. Ion chromatography from the dilutions of the commercial fertilizers (units: $\mathrm{mg} \cdot \mathrm{L}^{-1}$ ).

\begin{tabular}{|c|c|c|c|c|c|c|}
\hline Substance & Concentration & Ammonium & Potassium & Chloride & Nitrate & Phosphate \\
\hline \multirow{2}{*}{$\mathrm{KCl}$} & $\begin{array}{c}\text { Lowest } \\
\text { Concentration }\end{array}$ & 0.000 & 101.197 & 128.476 & 0.000 & 0.000 \\
\hline & $\begin{array}{c}\text { Highest } \\
\text { Concentration }\end{array}$ & 0.000 & 1020.555 & 854.058 & 0.000 & 0.000 \\
\hline \multirow{2}{*}{ KNO3 } & $\begin{array}{c}\text { Lowest } \\
\text { Concentration }\end{array}$ & 0.000 & 38.875 & 1.442 & 41.208 & 0.000 \\
\hline & $\begin{array}{c}\text { Highest } \\
\text { Concentration }\end{array}$ & 0.000 & 1055.488 & 0.000 & 1135.409 & 0.000 \\
\hline \multirow[t]{2}{*}{ Urea } & $\begin{array}{c}\text { Lowest } \\
\text { Concentration }\end{array}$ & 2.300 & 5.263 & 5.742 & 0.000 & 0.000 \\
\hline & $\begin{array}{c}\text { Highest } \\
\text { Concentration }\end{array}$ & 20.867 & 0.000 & 0.000 & 0.000 & 0.000 \\
\hline \multirow{2}{*}{ Superphosphate } & $\begin{array}{c}\text { Lowest } \\
\text { Concentration }\end{array}$ & 0.000 & 0.000 & 1.495 & 0.000 & 28.753 \\
\hline & $\begin{array}{c}\text { Highest } \\
\text { Concentration }\end{array}$ & 0.000 & 0.000 & 0.000 & 0.000 & 576.473 \\
\hline Dilution water & - & 0.000 & 2.079 & 0.649 & 0.000 & 0.000 \\
\hline
\end{tabular}

After the end of all assays it was possible to determine which was the most toxic substance and which organism was most sensitive to the tested fertilizer within $96 \mathrm{~h}$ of exposure (Figure 1).

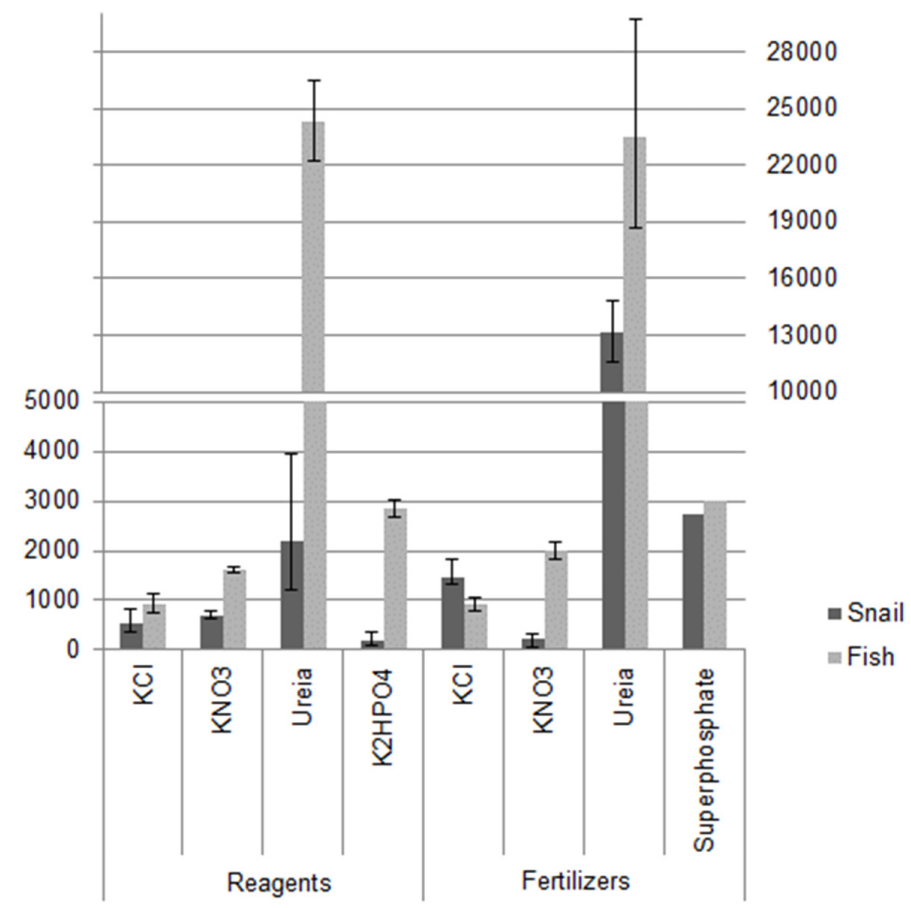

Figure 1. Lethal concentrations (LC50s) found for B. glabrata snail and D. rerio fish within $96 \mathrm{~h}$ of exposure (units: $\mathrm{mg} \cdot \mathrm{L}^{-1}$ ). Error bars represent $95 \%$ confidence intervals.

In the experiments involving the species B. glabrata and the calculated LC50 above, it is possible to see the difference in toxicity of the CR compared with that of the CF in all tested substances. The CR was more toxic than the $\mathrm{CF}$ in practically all cases, except for $\mathrm{KNO}_{3}$, where the opposite was observed. For D. rerio, only $\mathrm{KNO}_{3}$ showed a statistical difference in the toxicity of the $\mathrm{CR}$ in relation to the $\mathrm{CF}$. No other compound showed a difference because of the confidence interval limits.

From chemical analysis we performed the calculation of toxicity from each of the substances, which can be seen in the tables below. 
Table 3 shows that potassium toxicity was affected by the presence of other elements in the tested dilutions, since the potassium toxicity varied individually in function of the substance tested and the exposed organism. It was shown that $\mathrm{K}^{+}$in $\mathrm{KH}_{2} \mathrm{PO}_{4}$ was more toxic than $\mathrm{K}^{+}$in $\mathrm{KCl}$ and $\mathrm{KNO}_{3}$ (and there was no significant difference between them) for B. glabrata. However, for D. rerio, $\mathrm{K}^{+}$in $\mathrm{KCl}$ was more toxic than the one in $\mathrm{KNO}_{3}$ and $\mathrm{KH}_{2} \mathrm{PO}_{4}$ (and there were no significant differences between them).

Table 3. Comparison between the lethal concentrations (LC50s) obtained in different assays with potassium present for the reagent and the commercial fertilizer for the B. glabrata snail and the D. rerio fish (units $\mathrm{mg} \cdot \mathrm{L}^{-1}$ ). Values in brackets represent the $95 \%$ confidence intervals.

\begin{tabular}{|c|c|c|c|c|}
\hline \multirow{3}{*}{$\begin{array}{c}\text { Potassium in } \\
\text { Reagent }\end{array}$} & \multicolumn{4}{|c|}{ Chemical Reagent } \\
\hline & \multicolumn{2}{|c|}{$48 \mathrm{~h}$} & \multicolumn{2}{|c|}{$96 \mathrm{~h}$} \\
\hline & B. glabrata & D. rerio & B. glabrata & D. rerio \\
\hline $\mathrm{KCl}-\mathrm{K}$ & $\begin{array}{c}422.27 \\
(270.14-660.07)\end{array}$ & $\begin{array}{c}802.39 \\
(523.53-1229.78)\end{array}$ & $\begin{array}{c}277.98 \\
(183.58-420.92)\end{array}$ & $\begin{array}{c}527.91 \\
(432.64-644.16)\end{array}$ \\
\hline KNO3 - K & $\begin{array}{c}347.07 \\
(303.49-396.89)\end{array}$ & $\begin{array}{c}786.45 \\
(732.92-843.89)\end{array}$ & $\begin{array}{c}347.07 \\
(303.49-396.89)\end{array}$ & $\begin{array}{c}786.45 \\
(732.92-843.89)\end{array}$ \\
\hline КH2PO4 - K & $\begin{array}{c}90.32 \\
(33.11-246.34)\end{array}$ & $\begin{array}{c}811.47 \\
(690.15-954.12)\end{array}$ & $\begin{array}{c}44.26 \\
(19.83-98.75)\end{array}$ & $\begin{array}{c}774.16 \\
(721.89-830.21)\end{array}$ \\
\hline \multirow{3}{*}{$\begin{array}{l}\text { Potassium in } \\
\text { Fertilizer }\end{array}$} & \multicolumn{4}{|c|}{ Commercial Fertilizer } \\
\hline & \multicolumn{2}{|c|}{$48 \mathrm{~h}$} & \multicolumn{2}{|c|}{$96 \mathrm{~h}$} \\
\hline & B. glabrata & D. rerio & B. glabrata & D. rerio \\
\hline $\mathrm{KCl}-\mathrm{K}$ & $\begin{array}{c}891.98 \\
(801.01-993.29)\end{array}$ & $\begin{array}{c}589.25 \\
(502.64-690.79)\end{array}$ & $\begin{array}{c}785.20 \\
(610.17-1010.43)\end{array}$ & $\begin{array}{c}509.65 \\
(445.97-582.42)\end{array}$ \\
\hline KNO3 - K & $\begin{array}{c}139.90 \\
(111.63-175.33)\end{array}$ & $\begin{array}{c}993.65 \\
(944.33-1045.55)\end{array}$ & $\begin{array}{c}102.73 \\
(68.40-154.29)\end{array}$ & $\begin{array}{c}993.65 \\
(944.33-1045.55)\end{array}$ \\
\hline
\end{tabular}

Table 4, in turn, shows that nitrogen toxicity can be maximized because of its dissociation in water, since the compound as $\mathrm{NH}_{4}{ }^{+}$was showed to be more toxic than its form as $\mathrm{NO}_{3}{ }^{-}$. Moreover, the greater toxicity of $\mathrm{N}$ for $B$. glabrata can be associated with a higher intolerance of the species to the compound in relation to time, since the values at $96 \mathrm{~h}$ diverge from the others.

Table 4. Comparison between the lethal concentrations (LC50s) obtained in different assays with nitrogen present for the reagent and the commercial fertilizer for the B. glabrata snail and the D. rerio fish (units: $\mathrm{mg} \cdot \mathrm{L}^{-1}$ ). Values in brackets represent $95 \%$ confidence intervals.

\begin{tabular}{|c|c|c|c|c|}
\hline \multirow{3}{*}{$\begin{array}{l}\text { Nitrogen in } \\
\text { Reagent }\end{array}$} & \multicolumn{4}{|c|}{ Chemical Reagent } \\
\hline & \multicolumn{2}{|c|}{$48 \mathrm{~h}$} & \multicolumn{2}{|c|}{$96 \mathrm{~h}$} \\
\hline & B. glabrata & D. rerio & B. glabrata & D. rerio \\
\hline $\mathrm{KNO}_{3}-\mathrm{N}$ & $\begin{array}{c}354.09 \\
(311.55-402.44)\end{array}$ & $\begin{array}{c}856.23 \\
(825.64-887.95)\end{array}$ & $\begin{array}{c}354.09 \\
(311.55-402.44)\end{array}$ & $\begin{array}{c}856.23 \\
(825.64-887.95)\end{array}$ \\
\hline $\mathrm{CO}\left(\mathrm{NH}_{2}\right)_{2}-\mathrm{N}$ & $\begin{array}{c}0.81 \\
(0.62-1.05)\end{array}$ & $\begin{array}{c}9.05 \\
(8.36-9.81)\end{array}$ & $\begin{array}{c}0.10 \\
(0.001-17.73)\end{array}$ & $\begin{array}{c}8.55 \\
(8.08-9.04)\end{array}$ \\
\hline \multirow{3}{*}{$\begin{array}{l}\text { Nitrogen in } \\
\text { Fertilizer }\end{array}$} & \multicolumn{4}{|c|}{ Commercial Fertilizer } \\
\hline & \multicolumn{2}{|c|}{$48 \mathrm{~h}$} & \multicolumn{2}{|c|}{$96 \mathrm{~h}$} \\
\hline & B. glabrata & D. rerio & B. glabrata & D. rerio \\
\hline $\mathrm{KNO}_{3}-\mathrm{N}$ & $\begin{array}{c}153.38 \\
(125.98-186.87)\end{array}$ & $\begin{array}{c}988.01 \\
(878.70-1110.93)\end{array}$ & $\begin{array}{c}117.40 \\
(79.88-172.56)\end{array}$ & $\begin{array}{c}988.01 \\
(878.70-1110.93)\end{array}$ \\
\hline $\mathrm{CO}\left(\mathrm{NH}_{2}\right)_{2}-\mathrm{N}$ & $\begin{array}{c}8.51 \\
(5.38-13.45)\end{array}$ & $\begin{array}{c}6.28 \\
(4.65-8.48)\end{array}$ & $\begin{array}{c}3.39 \\
(2.89-3.99)\end{array}$ & $\begin{array}{c}6.28 \\
(4.65-8.48)\end{array}$ \\
\hline
\end{tabular}


When analyzing ammonium toxicity to the snail, low LC50 values were observed, reaching close to zero for the CR. This shows great sensitivity of the species to nitrogen in $\mathrm{NH}_{4}{ }^{+}$form. When the toxicity of ammonium in the urea compound for the fish is analyzed, it is noted that this has already raised mortality in very small concentrations, with LC50 under $20 \mathrm{mg} \cdot \mathrm{L}^{-1}$ being observed for all organisms. It is also possible to see more $\mathrm{NH}_{4}{ }^{+}$toxicity contained in the $\mathrm{CR}$ for B. glabrata in $48 \mathrm{~h}$ of exposure, but with no difference between both species when only results at $96 \mathrm{~h}$ are evaluated due to the large confidence interval.

For the phosphate anion, Table 5 showed that the toxicity was only compared between species, with B. glabrata being shown to be more sensitive to this element than $D$. rerio. These results, together with those obtained with $\mathrm{K}^{+}$as the donor source for the substance, showed that this ion is more responsible for the toxicity found for the fish than the $\mathrm{PO}_{4}{ }^{3-}$ for potassium phosphate monobasic substance.

Table 5. Comparison between the lethal concentrations (LC50s) obtained in different assays with phosphate present for the reagent and the commercial fertilizer for the B. glabrata snail and the D. rerio fish (units: $\mathrm{mg} \cdot \mathrm{L}^{-1}$ ). Values in brackets represent $95 \%$ confidence intervals.

\begin{tabular}{ccccc}
\hline \multirow{2}{*}{$\begin{array}{c}\text { Phosphate in Reagent and } \\
\text { in Fertilizer }\end{array}$} & B. glabrata & D. rerio & B. glabrata & D. rerio \\
\cline { 2 - 5 } & 260.75 & 2171.37 & 133.73 & 2056.98 \\
$\mathbf{K H}_{2} \mathbf{P O}_{4}-\mathbf{P O}_{4}$ & $(105.14-646.65)$ & $(1811.21-2603.15)$ & $(61.00-293.16)$ & $(1901.46-2225.22)$ \\
$\mathbf{C a}\left(\mathbf{H}_{\mathbf{2}} \mathbf{P O}_{4}\right)_{\mathbf{2}}+\mathrm{CaSO}_{4}-\mathbf{P O}_{4}$ & $>576.473$ & $>576.473$ & 515.26 & $>576.473$ \\
\hline
\end{tabular}

\section{Discussion}

When the toxicity data found for snails and for fish were compared, there was greater sensitivity of fish than snails to the $\mathrm{CF} \mathrm{KCl}$, unlike what was found for the CR.

However, when the toxicity found for $\mathrm{KCl}$ was compared with other species (Table 6), it was noted that in relation to the $\mathrm{CR}$ (Figure 1) no difference was found in $\mathrm{KCl}$ toxicity in similar tests at $48 \mathrm{~h}$. When compared with those obtained for $\mathrm{KCl}$ in $\mathrm{CF}$ (Figure 1), B. glabrata stands out from the others as the second-most resistant, behind only the insect $C$. triangulifer.

Table 6. Lethal or effective concentration and their confidence intervals (when present, shown in parentheses) for potassium chloride in studies with aquatic organisms.

\begin{tabular}{ccc}
\hline Species Name & $\begin{array}{c}\text { LC50/EC50 } \\
\text { (95\% Confidence Interval Limit) }\end{array}$ & Study \\
\hline Ceriodaphnia dubia & $630.0 \mathrm{mg} \cdot \mathrm{L}^{-1}(580-670)$ & Mount et al. (1997) [26] \\
Daphnia magna & $660.0 \mathrm{mg} \cdot \mathrm{L}^{-1}(440-880)$ & Mount et al. (1997) [26] \\
Daphnia similis & $986.66 \mathrm{mg} \cdot \mathrm{L}^{-1}(293.34-1313.32)$ & Utz and Böhrer (2001) [8] \\
Pimephales promelas & $910.0 \mathrm{mg} \cdot \mathrm{L}^{-1}(750-1090)$ & Mount et al. (1997) [26] \\
Piaractus mesopotamicus & $1370 \mathrm{mg} \cdot \mathrm{L}^{-1}$ & Ignácio et al. (2014) [27] \\
Centroptilum triangulifer & $1956.7 \mathrm{mg} \cdot \mathrm{L}^{-1}$ & Struewing et al. (2015) [28] \\
\hline
\end{tabular}

The toxicity data obtained for $\mathrm{KNO}_{3}$ showed higher sensitivity to the substance from B. glabrata than D. rerio, both for the $\mathrm{CR}$ and for the $\mathrm{CF}$ (Figure 1), but the snail also showed higher sensitivity to the $\mathrm{CF}$, while the fish showed higher sensitivity to the $\mathrm{CR}$. The results of the toxicity tests for $\mathrm{KNO}_{3}$ in this study showed less resistance among the organisms used than for others in the literature (Table 7). 
Table 7. Lethal or effective concentration for potassium nitrate in studies with aquatic organisms.

\begin{tabular}{lcl}
\hline \multicolumn{1}{c}{ Species Name } & LC50/EC50 & \multicolumn{1}{c}{ Study } \\
\hline Daphnia magna & $490 \mathrm{mg} \cdot \mathrm{L}^{-1}$ & Dowden and Bennet (1965) [29] \\
Lepomis macrochirus & $5500 \mathrm{mg} \cdot \mathrm{L}^{-1}$ & Dowden and Bennet (1965) [29] \\
Poecilia reticulata & $1380 \mathrm{mg} \cdot \mathrm{L}^{-1}$ & Rubin and Elmaraghy (1977) [30] \\
\hline
\end{tabular}

When results were compared both with the $\mathrm{CR}$ and with the $\mathrm{CF} \mathrm{KNO}_{3}$, all results showed the snail to be the second-most sensitive of all compared species, after the cladoceran. However, when the test results obtained with CF urea were compared, it was not possible to detect which species was more sensitive to fertilizer because of the confidence interval limits of $48 \mathrm{~h}$ of exposure. However, with the 96-h results, the snail was more sensitive than the zebrafish to the CF.

The data of this study compared with similar ones in the literature show that urea is also toxic to other species only at high concentrations (Table 8).

Table 8. Lethal or effective concentration and their confidence intervals (when present, shown in parentheses) for urea in studies with aquatic organisms.

\begin{tabular}{|c|c|c|}
\hline Species Name & $\begin{array}{c}\text { LC50/EC50 } \\
\text { (95\% Confidence Intervals) }\end{array}$ & Study \\
\hline Biomphalaria havanensis & $\begin{array}{l}21,412.08 \mathrm{mg} \cdot \mathrm{L}^{-1} \\
(19,269.66-23,538.43)\end{array}$ & Tchounwou et al. (1991) [31] \\
\hline Helisoma trivolvis & $\begin{array}{l}13,476.59 \mathrm{mg} \cdot \mathrm{L}^{-1} \\
(11,957.82-14,888.23)\end{array}$ & Tchounwou et al. (1991) [31] \\
\hline Eobania vermiculata & $54,860 \mathrm{mg} \cdot \mathrm{L}^{-1}$ & Eshra (2014) [32] \\
\hline Theba pisana & $48,860 \mathrm{mg} \cdot \mathrm{L}^{-1}$ & Eshra (2014) [32] \\
\hline Catla catla & $280 \mathrm{mg} \cdot \mathrm{L}^{-1}(260-280)$ & Sangeetha et al. (2011) [33] \\
\hline Rana sylvatica & $14,370 \mathrm{mg} \cdot \mathrm{L}^{-1}(12,400-16,110)$ & Harless et al. (2011) [34] \\
\hline
\end{tabular}

All results presented in these studies, when compared with the results for the organisms used in the present study (Figure 1), indicate that B. glabrata is the most sensitive to urea as a reagent. However, if only the CF is analyzed, the species $C$. catla appears to be the most sensitive, followed by $R$. sylvatica, B. glabrata, and D. rerio together.

The higher sensitivity of $B$. glabrata to urea can be explained by the fact that this substance has a molluscicidal effect [35], but although urea has this effect on snails, B. glabrata was more sensitive than the freshwater snails used by Tchounwou et al. [31]. This may be related to the type of bioassay that was used, because in this study there was daily renewal of test solutions, and in the work of these authors the exposure methodology was not explained.

From the results in Table 9 it could be seen that the snail was the most sensitive species for the superphosphate at $96 \mathrm{~h}$ exposure, but in the 48 -h test it was not possible to define which species is most sensitive to fertilizer. The most susceptible species to $\mathrm{KH}_{2} \mathrm{PO}_{4}$ was also B. glabrata based on data found in Figure 1.

The results found in the literature for $\mathrm{KH}_{2} \mathrm{PO}_{4}$ show greater resistance of zebrafish over other species. In a study involving the zebra mussel (Dreissena polymorpha) (LC50 $=92 \mathrm{mg} \cdot \mathrm{L}^{-1}$ ) and the Asian clam (Corbicula fluminea), Fisher et al. [17] found very different toxicity values for these closely related organisms, making it impossible to find mortality for the species $C$. fluminea in concentrations up to $2000 \mathrm{mg} \cdot \mathrm{L}^{-1}$ of $\mathrm{KH}_{2} \mathrm{PO}_{4}$ in $24 \mathrm{~h}$. In addition to this author, Reish [36], working with the tolerance of polychaete Nereis grubei, Neanthes arenaceodentata, Dorvillea articulate, and Capitella capitata to the substance $\mathrm{KH}_{2} \mathrm{PO}_{4}$, obtained mean values of tolerance equal to $0.920 \mathrm{mg} \cdot \mathrm{L}^{-1}, 1.900 \mathrm{mg} \cdot \mathrm{L}^{-1}$, $2.100 \mathrm{mg} \cdot \mathrm{L}^{-1}$, and $2.400 \mathrm{mg} \cdot \mathrm{L}^{-1}$, respectively, for the test-species.

For $\mathrm{CF}$, the toxicity observed for snails only at a concentration of $3000 \mathrm{mg} \cdot \mathrm{L}^{-1}$ superphosphate can be explained from the moment that Vieira and Ramos [37] report that when the calcium concentration 
in water is above $120 \mathrm{mg} \cdot \mathrm{L}^{-1}$, phosphate fertilizers tend to precipitate. Therefore, it is possible to assume that the presence of calcium in the dilution water, plus calcium present in high concentrations of superphosphate promoted, the precipitation of phosphate in water. Since B. glabrata has a benthic habit, its mortality may be because of the decantation of the substance. Moreover, even if the presence of calcium in water is beneficial for the formation of the snail shell, B. glabrata can only tolerate concentrations of up to $120 \mathrm{mg} \cdot \mathrm{L}^{-1}$ calcium [38].

Table 9. Lethal or effective concentrations and their confidence intervals (when present, shown in parentheses) for potassium phosphate monobasic in studies with aquatic organisms.

\begin{tabular}{ccc}
\hline Species Name & $\begin{array}{c}\text { LC50/EC50 } \\
(\mathbf{9 5 \%} \text { Confidence Interval Limit) }\end{array}$ & Study \\
\hline Oreochromis niloticus & $3760 \mathrm{mg} \cdot \mathrm{L}^{-1}(2990-4010)$ & Omoregie et al. (2009) [39] \\
Chironomus yoshimatsui & $1520 \mathrm{mg} \cdot \mathrm{L}^{-1}$ & Kegley et al. (2014) [40] \\
Viviparus bengalensis & $2280 \mathrm{mg} \cdot \mathrm{L}^{-1}$ & Kegley et al. (2014) [40] \\
Radix luteola & $3000 \mathrm{mg} \cdot \mathrm{L}^{-1}$ & USEPA, (2015) [41] \\
\hline
\end{tabular}

In a study which also aimed to observe phosphate toxicity to aquatic organisms of three different trophic levels (fish, algae, and cladocerans), involving the compounds tricalcium phosphate $\left(\mathrm{Ca}_{3}\left(\mathrm{PO}_{4}\right)_{2}\right)$ and calcium hydrogenorthophosphate $\left(\mathrm{CaHPO}_{4}\right)$, Kim et al. [18] could not specifically stipulate phosphate toxicity to the organisms tested, because the low solubility of the phosphate prevents assays from being performed in concentrations above $100 \mathrm{mg} \cdot \mathrm{L}^{-1}$. Both in our study and in the research of Kim et al. [18] it can be seen that there is a difficulty in determining phosphate toxicity to aquatic organisms due to the low solubility of this compound and its tendency to precipitate in the presence of calcium.

From the data found for the snail and those listed in Table 9, it is possible to estimate that the toxicity to the fish should be above $4000 \mathrm{mg} \cdot \mathrm{L}^{-1}$ superphosphate, since Omoregie et al. [39] working with Nile tilapia (Oreochromis niloticus) found a similar value.

The toxicological data of the individual elements in the tests with the CR (Table 3) showed that B. glabrata tends to be more resistant to potassium separately. Indeed, the Brazilian Ministry of Health publication on the control of mollusks [42] shows that this species is resistant to concentrations between 0.1 to $54.5 \mathrm{mg} \cdot \mathrm{L}^{-1}$ of potassium, and in this study all of the calculated LC50s for B. glabrata, and their confidence interval limits, were above this value.

When comparing the toxicity values obtained in this study and listed in Table 3 with others in the literature, the tested snails showed greater LC50 for potassium in the 48-h test than in that performed by Freitas and Rocha [43] with the cladoceran Pseudosida ramosa $\left(\mathrm{LC} 50=17.7 \mathrm{mg} \cdot \mathrm{L}^{-1}\right)$. However, all of these results were lower than $D$. rerio for $\mathrm{KCl}, \mathrm{KNO}_{3}$, and $\mathrm{KH}_{2} \mathrm{PO}_{4}$, and the results obtained by Vijayavel and Balasubramanian [44] for the Mozambique tilapia (Oreochromis mossambicus) in the 96-h test $\left(\mathrm{LC} 50=569.25 \mathrm{mg} \cdot \mathrm{L}^{-1}\right)$. This showed that in a potassium tolerance range, $P$. ramosa was the most sensitive, followed by B. glabrata, and the most resistant were the fish $D$. rerio and O. mossambicus.

For nitrogen, different forms of this had different toxicity values for the species, with nitrogen in the form of ammonia $\left(\mathrm{NH}_{3}\right)$ or ammonium $\left(\mathrm{NH}_{4}{ }^{+}\right)$being generally more toxic than nitrogen in nitrate form $\left(\mathrm{NO}_{3}{ }^{-}\right)[3,45,46]$. B. glabrata and D. rerio were demonstrated to be more sensitive than other species to $\mathrm{NO}_{3}{ }^{-}$ions when comparing the data contained in Table 4 with tests performed with sodium nitrate $\left(\mathrm{NaNO}_{3}\right)$ in other organisms. As an example, we can mention the test performed by Alonso and Camargo [45] with the aquatic snail Potamopyrgus antipodarum, which had LC50 equal to $1042 \mathrm{mg} \cdot \mathrm{L}^{-1}$, while the test conducted by Hamlin [46] with the Siberian sturgeon (Acipenser baerii) had toxicity equal to $1028 \mathrm{mg} \cdot \mathrm{L}^{-1}$; all of these tests took place after $96 \mathrm{~h}$ of exposure. With the $48 \mathrm{~h}$ of exposure results, there was only a difference when compared again with LC50 values for the A. baerii $\left(\mathrm{LC} 50=1443 \mathrm{mg} \cdot \mathrm{L}^{-1}\right)[46]$ and the fathead minnow P. promelas $\left(\mathrm{LC} 50=1341 \mathrm{mg} \cdot \mathrm{L}^{-1}\right)$, but without 
a difference for C. dubia and D. magna Cladocera (LC50 $=374 \mathrm{mg} \cdot \mathrm{L}^{-1}$ and $462 \mathrm{mg} \cdot \mathrm{L}^{-1}$, respectively) found by Scott and Crunkilton [47], due to the limits of the confidence interval.

When comparing the results with $\mathrm{KNO}_{3}$ as donor source of $\mathrm{NO}_{3}{ }^{-}$for the tests, B. glabrata and $D$. rerio were more resistant when compared with the guppy fish ( $P$. reticulata) in the assays performed by Rubin and Elmaraghy [30], where the toxicity was equal to $191 \mathrm{mg} \cdot \mathrm{L}^{-1}$ after $96 \mathrm{~h}$ of exposure.

The toxicity data for $\mathrm{NH}_{4}{ }^{+}$(Table 4) showed higher sensitivity of B. glabrata in relation to the others. The snail P. antipodarum in Alonso and Camargo's test [45] was the second most vulnerable species, with LC50 equal to $2.23 \mathrm{mg} \cdot \mathrm{L}^{-1}$, followed by pacú fish (P. mesopotamicus) with LC50 equal to $3.98 \mathrm{mg} \cdot \mathrm{L}^{-1}$ [15], D. rerio and guppy (P. reticulata), with a toxicity value equal to $93.9 \mathrm{mg} \cdot \mathrm{L}^{-1}$ [30], the latter being the most resistant species to $\mathrm{NH}_{4}{ }^{+}$if only the 48-h results are analyzed. Examining the 96-h data, due to the large confidence interval that B. glabrata showed, it was not possible to see any difference between this organism and the other, leaving only P. reticulata as the most resistant (LC50 equal to $91.2 \mathrm{mg} \cdot \mathrm{L}^{-1}$ ).

The higher survival of fish for ammonia in relation to other species may be due to the fact that these organisms are more susceptible to the un-ionized form of ammonia $\left(\mathrm{NH}_{3}\right)$ than its ionized form, or ammonium form $\left(\mathrm{NH}_{4}{ }^{+}\right)$, since fish membranes are more permeable to $\mathrm{NH}_{3}$ than to $\mathrm{NH}_{4}{ }^{+}[13,14]$. This fact becomes clear when studies that aimed to compare the toxicity of $\mathrm{NH}_{3}$ with $\mathrm{NH}_{4}{ }^{+}$in fish are analyzed. The calculated lethal concentrations for $\mathrm{NH}_{3}$ within the first $24 \mathrm{~h}$ of exposure ranged from 0.023 to $0.85 \mathrm{mg} \cdot \mathrm{L}^{-1}$ in function of exposed fish species [14,15].

The extreme vulnerability of $B$. glabrata to ammonium in urea was not expected, since it is known that this species can survive in concentrations from 0.1 to $2.6 \mathrm{mg} \cdot \mathrm{L}^{-1} \mathrm{NH}_{3}$ [42], and when other snail species are exposed to ammonium sources derived from CR (as ammonium sulfate) and CF (as urea), they did not obtain the same mortality as the species in our study. Toxicity values ranging from 490.79 to $700.73 \mathrm{mg} \cdot \mathrm{L}^{-1}$ were reported for ammonium sulfate [31] and from 48.86 to $54.86 \mathrm{mg} \cdot \mathrm{L}^{-1}$ for urea [32].

Due to the lack of studies addressing phosphate toxicity in the available literature, the use of Ecotox database [41] and Pesticide Info database [40] was required to find LC50 values to have a criterion for comparing our study with others. The search criteria were the substances $\mathrm{H}_{3} \mathrm{PO}_{4}$, $\mathrm{Na}_{2} \mathrm{HPO}_{4}, \mathrm{NaH}_{2} \mathrm{PO}_{4}, \mathrm{CaHPO}_{4}, \mathrm{Ca}\left(\mathrm{H}_{2} \mathrm{PO}_{4}\right)_{2}$, and $\mathrm{Ca}_{3}\left(\mathrm{PO}_{4}\right)_{2}$ for being phosphate sources when diluted; only tests that covered the period of 48 and $96 \mathrm{~h}$ of exposure were sought.

The toxicity data for $\mathrm{PO}_{4}{ }^{3-}$ showed that there is some difficulty in defining the toxicity of this ion to aquatic organisms, and probably its interaction with other compounds can interfere in its toxicity, as highlighted by Fisher et al. [17]. Kim et al. [18] could not define the toxicity of $\mathrm{PO}_{4}{ }^{3-}$ for the amphidromous fish Oryzias latipes and the cladoceran D. magna, using the compounds $\mathrm{CaHPO}_{4}$ and $\mathrm{Ca}_{3}\left(\mathrm{PO}_{4}\right)_{2}$ as phosphate source, but when it interacts with sodium, the phosphate appears to be less toxic than other variations, since toxicity values were found equal to $3580 \mathrm{mg} \cdot \mathrm{L}^{-1}$ for $D$. magna and $720 \mathrm{mg} \cdot \mathrm{L}^{-1}$ for the mosquito-fish fry (Gambusia affinis) in 48-h assays. The most toxic form of the phosphate appears to be phosphoric acid $\left(\mathrm{H}_{3} \mathrm{PO}_{4}\right)$, with toxicity values equal to $60 \mathrm{mg} \cdot \mathrm{L}^{-1}$ and $87 \mathrm{mg} \cdot \mathrm{L}^{-1}$ being found for the freshwater bluegill sunfish (L. macrochirus) and the rainbow trout (Oncorhynchus mykiss), respectively, in $96-\mathrm{h}$ assays and $138 \mathrm{mg} \cdot \mathrm{L}^{-1}$ for G. affinis at $48 \mathrm{~h}[40,41]$.

For $\mathrm{KH}_{2} \mathrm{PO}_{4}$ data found in this study (Table 5), B. glabrata showed toxicity data inside the confidence limit that other species had to $\mathrm{H}_{3} \mathrm{PO}_{4}$, but $D$. rerio showed higher tolerance to $\mathrm{KH}_{2} \mathrm{PO}_{4}$.

Based on the results of our study for the $\mathrm{KH}_{2} \mathrm{PO}_{4}$ presented in Table 5, and the ones found in the literature, it can be noted that the phosphate present in $\mathrm{Na}_{2} \mathrm{HPO}_{4}, \mathrm{NaH}_{2} \mathrm{PO}_{4}, \mathrm{CaHPO}, \mathrm{Ca}\left(\mathrm{H}_{2} \mathrm{PO}_{4}\right)_{2}$, and $\mathrm{Ca}_{3}\left(\mathrm{PO}_{4}\right)_{2}$ is less toxic than that present in $\mathrm{KH}_{2} \mathrm{PO}_{4}$ and $\mathrm{H}_{3} \mathrm{PO}_{4}$ when only acute toxicity data are analyzed. However, it is worth noting that data from chronic toxicity to O. mykiss shown by Satoh et al. [48] showed the opposite of those found for acute toxicity. In the latter, the mortality was higher in sodium phosphate and potassium phosphate in the long-term, and the survival was higher in phosphoric acid and calcium phosphate, but with growth reduced in the latter one. 
It is emphasized that for all of the ecotoxicological tests compared here, the differences in the toxicity observed may not only be related to the substance or the compound itself, but also to the life stage of the organism used in the assay. It is known that younger organisms tend to be more susceptible than adult organisms [23]. Given the results presented here, it can be concluded that the fertilizers $\mathrm{KCl}, \mathrm{KNO}_{3}$, and urea have toxic effects on B. glabrata and D. rerio, with the zebrafish being more susceptible to $\mathrm{KCl}$ present in fertilizer and the snail to the other compounds. In the present study, it was only possible to establish a difference between the toxicity to the snail of CF and of CR.

\section{Conclusions}

Faced with the data presented, it can be concluded that $\mathrm{KCl}, \mathrm{KNO}_{3}$, and urea fertilizers have acute toxic effects on B. glabrata and D. rerio. The fish is more susceptible to $\mathrm{KCl}$ as a commercial fertilizer (CF), and the snail to $\mathrm{KNO}_{3}$ and to urea, both as a chemical reagent (CR). Regarding the superphosphate, significant toxicity values were not found.

Within the presented data, it was possible to conclude that among the CRs, the most toxic was potassium phosphate $\left(\mathrm{KH}_{2} \mathrm{PO}_{4}\right)$ to the snail and potassium chloride $(\mathrm{KCl})$ to the fish; urea was the least toxic for both organisms. Among the commercial fertilizers ( $\mathrm{CFs}), \mathrm{KNO}_{3}$ was more toxic to Biomphalaria glabrata snails, and again $\mathrm{KCl}$ was more toxic for the fish Danio rerio. Once again, urea was the least toxic $\mathrm{CF}$ for both organisms.

It was not possible to establish the most sensitive species, since in some cases one species was more susceptible to a $\mathrm{CF}$ and another to $\mathrm{CR}$, This was the case for $\mathrm{KCI}$, where the fish was more susceptible to the $\mathrm{CF}$ and the snail to the $\mathrm{CR}$, while for $\mathrm{KNO}_{3}$ the opposite was observed.

Acknowledgments: This work was financed by the Brazilian National Council of Scientific and Technological Development (CNPq), Project 478637/2012-8. Our authors received a grant from the projects CNPq $n^{\circ}$ 561944/2010-5; CNPq 483410/2011-0 and SEG - Embrapa 021101027.

Author Contributions: The authors Eduardo Cyrino Oliveira-Filho and Nathan de Castro Soares Simplício conceived and designed the experiment and analyzed the data; Bruno Pereira Costa, Denis Cavalcanti Martins, Fernanda Regina Moreira Rocha and Zélia Malena Barreira Dias conducted the experiments; Daphne Heloísa de Freitas Muniz and Eduardo Cyrino Oliveira-Filho contributed with analysis tools and were responsible for overseeing the development of work and reviewing the versions of the manuscript; Nathan de Castro Soares Simplício wrote the paper.

Conflicts of Interest: The authors declare no conflict of interest.

\section{References}

1. IFA (International Fertilizer Industry Association). Assessment of Fertilizer Use by Crop at the Global Level; IFA: Paris, France, 2013. Available online: http:/ / www.fertilizer.org (accessed on 5 September 2016).

2. APHA (American Public Health Association). Standard Methods for the Examination of Water and Wastewater, 22nd ed.; American Public Health Association: Washington, DC, USA, 2005.

3. Camargo, J.A.; Alonso, A.; Salamanca, A. Nitrate toxicity to aquatic animals: A review with new data for freshwater invertebrates. Chemosphere 2005, 58, 1255-1267. [CrossRef] [PubMed]

4. $\quad$ ESTEVES, F.A. Fundamentos de Limnologia, 2nd ed.; Interciência: Rio de Janeiro, Brazil, 1998.

5. Vilela, L.; Sousa, D.M.G.; Silva, J.E. Adubação potássica. In Cerrado: Correção do solo e adubação; Sousa, D.M.G., Lobato, E., Eds.; Embrapa Informação Tecnológica: Brasília, Brazil, 2004.

6. Rosolem, C.A.; Vicentini, J.P.T.M.M.; Steiner, F. Suprimento de potássio em função da adubação potássica residual em um Latossolo Vermelho do Cerrado. Rev. Bras. Ciênc. Solo 2012, 36, 1507-1515. [CrossRef]

7. Resende, A.V.; Martins, E.S.; Oliveira, C.G.; Sena, M.C.; Machado, C.T.T.; Kinpara, D.I.; Oliveira-Filho, E.C. Suprimentos de potássio e pesquisa de uso de rochas "in natura" na agricultura brasileira. Espaço Geogr. 2006, 9, 19-42. Available online: http://www.lsie.unb.br/espacoegeografia/index.php?journal=espacoegeografia\& page $=$ article\&op $=$ view \&path $\% 5 B \% 5 \mathrm{D}=46 \&$ path $\% 5 \mathrm{~B} \% 5 \mathrm{D}=45$ (accessed on 21 September 2016).

8. Utz, L.R.P.; Böhrer, M.B.C. Acute and chronic toxicity of potassium chloride $(\mathrm{KCl})$ and potassium acetate $\left(\mathrm{KC}_{2} \mathrm{H}_{3} \mathrm{O}_{2}\right)$ to Daphnia similis and Ceriodaphnia dubia (Crustacea; Cladocera). Bull. Environ. Contam. Toxicol. 2001, 66, 379-385. [CrossRef] [PubMed] 
9. Romano, N.; Zeng, C. Acute toxicity of sodium nitrate, potassium nitrate, and potassium chloride and their effects on the hemolymph composition and gill structure of early juvenile blues swimmer crabs (Portunus pelagicus Linnaeus, 1758) (Decapoda, Brachyura, Portunidae). Environ. Toxicol. Chem. 2007, 26, 1955-1962. [CrossRef] [PubMed]

10. Menció, A.; Mas-Pla, J.; Otero, N.; Regàs, O.; Boy-Roura, M.; Puig, R.; Bach, J.; Domènech, C.; Zamorano, M.; Brusi, D.; et al. Nitrate pollution of groundwater; all right ... , but nothing else? Sci. Total Environ. 2016, 539, 241-251. [CrossRef] [PubMed]

11. Zagatto, P.A. Ecotoxicologia. In Ecotoxicologia aquática: Princípios e aplicações; Zagatto, P.A., Bertoletti, E., Eds.; Rima: São Carlos, Brazil, 2006; pp. 1-13.

12. Oliveira-Filho, E.C. Avaliação da toxicidade. In Princípios de Toxicologia Ambiental; Sisinno, C.L.S., Oliveira-Filho, E.C., Eds.; Interciência: Rio de Janeiro, Brazil, 2013.

13. Camargo, J.A.; Alonso, A. Ecological and toxicological effects of inorganic nitrogen pollution in aquatic ecosystems: A global assessment. Environ. Int. 2006, 32, 831-849. [CrossRef] [PubMed]

14. Martinez, C.B.R.; Azevedo, F.; Winkaler, E.U. Toxicidade e efeitos da amônia em peixes neotropicais. In Tópicos Especiais em Biologia Aquática e Aqüicultura; Cyrino, J.E.P., Urbinati, E.C., Eds.; Sociedade Brasileira Aqüicultura e Biologia aquática: Jaboticabal, Brazil, 2006; pp. 81-95.

15. Barbieri, E.; Bondioli, A.C.V. Acute toxicity of ammonia in pacu fish (Piaractus mesopotamicus, Holberg, 1887) at different temperature levels. Aquac. Res. 2015, 46, 565-571. [CrossRef]

16. Penttinen, S.; Malk, V.; Väisänen, A.; Penttinen, O.P. Using the critical body residue approach to determine the acute toxicity of cadmium at varying levels of water hardness and dissolved organic carbon concentrations. Ecotoxicol. Environ. Saf. 2011, 74, 1151-1155. [CrossRef] [PubMed]

17. Fisher, S.W.; Stromberg, P.; Bruner, K.A.; Boulet, L.D. Molluscicidal activity of potassium to the zebra mussel, Dreissena polymorphia: Toxicity and mode of action. Aquat. Toxicol. 1991, 20, 219-234. [CrossRef]

18. Kim, E.; Yoo, S.; Ro, H.Y.; Han, H.J.; Baek, Y.W.; Eom, I.C.; Kim, H.M.; Kim, P.; Choi, K. Aquatic toxicity assessment of phosphate compounds. Environ. Health Toxicol. 2013, 28, 1-7. [CrossRef]

19. Sousa, D.M.G.; Lobato, E. Calagem e adubação para culturas anuais e semiperenes. In Cerrado: Correção do solo e adubação; Sousa, D.M.G., Lobato, E., Eds.; Embrapa Informação Tecnológica: Brasília, Brazil, 2004.

20. Oliveira-Filho, E.C.; Geraldino, B.R.; Grisolia, C.K.; Paumgartten, F.J.R. Acute Toxicity of Endosulfan, Nonylphenol Ethoxylate and Ethanol to Different Life Stages of the Freshwater Snail Biomphalaria tenagophila (Orbigny, 1835). Bull. Environ. Contam. Toxicol. 2005, 75, 1185-1190. [CrossRef] [PubMed]

21. ABNT (Associação Brasileira de Normas Técnicas). Ecotoxicologia aquática - Toxicidade aguda - Método de ensaio com peixes. NBR 15088; ABNT: Rio de Janeiro, Brazil, 2004.

22. Hamilton, M.A.; Russo, R.C.; Thurston, R.V. Trimmed Spearman-Karber method for estimating median lethal concentrations in toxicity bioassays. Environ. Sci. Technol. 1977, 11, 714-719. [CrossRef]

23. USEPA (U.S. Environmental Protection Agency). Methods for Measuring the Acute Toxicity of Effluents and Receiving Waters to Freshwaters and Marine Organisms; EPA-821-R-02-012, 4th ed.U.S. Environmental Protection Agency: Washington, DC, USA, 2002.

24. Frankenberger, W.F., Jr.; Mehra, H.C.; Gjerd, D.T. Environmental applications of ion chromatography. J. Chromatogr. 1990, 504, 211-245. [CrossRef]

25. R Core Team. R: A language and environment for statistical computing. In $R$ Foundation for Statistical Computing; R Core Team: Vienna, Austria. Available online: http://www.r-project.org/ (accessed on 5 September 2016).

26. Mount, D.R.; Gulley, D.D.; Hocket, T.J.R.; Garrison, T.D.; Evans, J.M. Statistical models to predict the toxicity of major ions to Ceriodaphnia dubia, Daphnia magna and Pimephales promelas (fathead minnows). Environ. Toxicol. Chem. 1997, 16, 2009-2019. [CrossRef]

27. Ignácio, N.F.; Américo, J.H.P.; Silva, M.A.; Carraschi, S.P.; Ikefuti, C.V.; Cruz, C.; Machado-Neto, J.G. Classificação ecotoxicológica do inseticida Fipronil para o peixe de espécie pacu. Congresso Nacional de Meio Ambiente de Poços de Caldas 2014, 6. Available online: http:/ / meioambientepocos.com.br/portal/anais/2014/ index.php (accessed on 5 September 2016).

28. Struewing, K.A.; Lazorchak, J.M.; Weaver, P.C.; Johnson, B.R.; Funk, D.H.; Buchwalter, D.B. Part 2: Sensitivity comparisons of the mayfly Centroptilum triangulifer to Ceriodaphnia dubia and Daphnia magna using standard reference toxicants; $\mathrm{NaCl}, \mathrm{KCl}$ and $\mathrm{CuSO}_{4}$. Chemosphere 2015, 149, 597-603. [CrossRef] [PubMed] 
29. Dowden, B.F.; Bennet, H.J. Toxicity of selected chemicals to certain animals. J. Water Poll. Control Fed. 1965, 37, 1308-1316. Available online: http:/ /www.jstor.org/stable/25035374 (accessed on 22 September 2016).

30. Rubin, A.J.; Elmaraghy, G.A. Studies on the toxicity of ammonia, nitrate and their mixtures to guppy fry. Water Res. 1977, 11, 927-935. [CrossRef]

31. Tchounwou, P.B.; Englande, A.J., Jr.; Malek, E.A. Toxicity evaluation of ammonium sulphate and urea to three developmental stages of freshwater snails. Arch. Environ. Contam. Toxicol. 1991, 21, 359-364. [CrossRef] [PubMed]

32. Eshra, E.H. Toxicity of methomyl, copper hydroxide and urea fertilizer on some land snails. Ann. Agric. Sci. 2014, 59, 281-284. [CrossRef]

33. Sangeetha, S.; Sujatha, K.; Senthilkumaar, P.; Kalyanaraman, V.; Eswari, S. Acute toxicity of some agriculture fertilizers to fingerlings of Catla catla. Indian J. Sci. Technol. 2011, 4, 770-772. Available online: http://www.indjst.org/index.php/indjst/article/view/30108 (accessed on 22 September 2016).

34. Harless, M.L.; Huckins, C.J.; Grant, J.B.; Pypker, T.G. Effects of six chemical deicers on larval wood frogs (Rana sylvatica). Environ. Toxicol. Chem. 2011, 30, 1637-1641. [CrossRef] [PubMed]

35. Perret, P.; Egger, M.; Degremont, A.A. Essai de lutte anti-mollusque par augmentation de la biomasse planctonique et traitement molluscicide: Association Urée-N-tritylmorpholine. Acta Tropica 1972, 29, $175-181$. [PubMed]

36. Reish, D.L. The effects of varying concentrations of nutrient, chlorinity, and dissolved oxygen on polychaetous annelids. Water Res. 1970, 4, 721-735. [CrossRef]

37. Vieira, R.F.; Ramos, M.M. Fertirrigação. In Recomendações para o uso de corretivos e fertilizantes em Minas Gerais; Ribeiro, A.C., Guimarães, P.T.G., Alvarez, V.V.H., Eds.; Comissão de Fertilidade do Solo do Estado de Minas Gerais: Viçosa, Brazil, 1999.

38. Oliveira-Filho, E.C.; Caixeta, N.R.; Simplicio, N.C.S.; Sousa, S.R.; Aragão, T.P.; Muniz, D.H.F. Implications of water hardness in ecotoxicological assessments for water quality regulatory purposes: A case study with the snail Biomphalaria glabrata (Say, 1818). Braz. J. Biol. 2014, 74, 175-180. [CrossRef] [PubMed]

39. Omoregie, E.; Ajima, M.N.O.; Keke, R.I.; Wieski, K. Effect of single superphosphate fertilizer on survival and respiratory dynamics of Nile tilapia, Oreochromis niloticus (Actinopterygii: Perciformes: Cichlidae). Acta Ichthyol. Piscat. 2009, 39, 103-110. [CrossRef]

40. Kegley, S.E.; Hill, B.R.; Choi, A.H. PAN Pesticide Database; Pesticide Action Network: Oakland, CA, USA, 2014. Available online: http://www.pesticideinfo.org/ (accessed on 5 September 2016).

41. USEPA. ECOTOX User Guide: ECOTOXicology Database System. Version 4.0. Available online: http:/www.epa.gov/ecotox/ (accessed on 5 September 2016).

42. Ministry of Health. Vigilância e Controle de Moluscos de Importância Epidemiológica, 2nd ed.; Editora do Ministério da Saúde: Brasília, Brazil, 2007.

43. Freitas, E.C.; Rocha, O. Acute and chronic effects of sodium and potassium on the tropical freshwater cladoceran Pseudosida ramosa. Ecotoxicology 2011, 20, 88-96. [CrossRef] [PubMed]

44. Vijayavel, K.; Balasubramanian, M.P. Interaction of potash and decis in the ecophysiology of a freshwater fish Oreochromis mossambicus. Ecotoxicol. Environ. Saf. 2007, 66, 154-158. [CrossRef] [PubMed]

45. Alonso, A.; Camargo, J.A. Short-term toxicity of ammonia, nitrite, and nitrate to the aquatic snail Potamopyrgus antipodarum (Hydrobiidae, Mollusca). Bull. Environ. Contam. Toxicol. 2003, 70, 1006-1012. [CrossRef] [PubMed]

46. Hamlin, H.J. Nitrate toxicity in Siberian sturgeon (Acipenser baeri). Aquaculture 2006, 253, 688-693. [CrossRef]

47. Scott, G.; Crunkilton, R.L. Acute and chronic toxicity of nitrate to fathead minnows (Pimephales promelas), Ceriodaphnia dubia, and Daphnia magna. Environ. Toxicol. Chem. 2000, 19, 2918-2922. [CrossRef]

48. Satoh, S.; Porn-Ngam, N.; Takeuchi, T.; Watanabe, T. Effect of various types of phosphate on zinc availability to rainbow trout. Nippon Suisan Gakkaishi 1993, 59, 1395-1400. [CrossRef]

(C) 2016 by the authors; licensee MDPI, Basel, Switzerland. This article is an open access article distributed under the terms and conditions of the Creative Commons Attribution (CC-BY) license (http://creativecommons.org/licenses/by/4.0/). 